\title{
Chromosomal gains in the sarcomatoid transformation of chromophobe renal cell carcinoma
}

\author{
Matteo Brunelli ${ }^{1}$, Stefano Gobbo ${ }^{1}$, Paolo Cossu-Rocca ${ }^{2}$, Liang Cheng ${ }^{3}$, Ondrej Hes ${ }^{4}$, \\ Brett Delahunt ${ }^{5}$, Maurizio Pea ${ }^{1}$, Franco Bonetti ${ }^{1}$, Maria M Mina ${ }^{1}$, Vincenzo Ficarra ${ }^{6}$, \\ Marco Chilosi ${ }^{1}$, John N Eble ${ }^{3}$, Fabio Menestrina ${ }^{1}$ and Guido Martignoni ${ }^{1}$ \\ ${ }^{1}$ Anatomia Patologica, Dipartimento di Patologia, Università di Verona, Verona, Italy; ${ }^{2}$ Anatomia Patologica, \\ Università di Sassari, Sassari Italy; ${ }^{3}$ Department of Pathology, Indiana University School of Medicine, \\ Indianapolis, IN, USA; ${ }^{4}$ Department of Pathology, University Hospital Plzen, Plzen, Czech Republic; \\ ${ }^{5}$ Department of Pathology, Wellington School of Medicine, Wellington South, New Zealand and \\ ${ }^{6}$ Dipartimento di Urologia, Università di Verona, Verona, Italy
}

\begin{abstract}
The hallmark of chromophobe renal cell carcinoma is multiple chromosomal losses from among chromosomes $1,2,6,10$ and 17. Chromophobe renal cell carcinoma with distant metastases or sarcomatoid transformation are uncommon and little is known about their chromosomal abnormalities. We collected six sarcomatoid chromophobe renal cell carcinomas and three primary chromophobe renal cell carcinomas with distant metastases. A cytogenetic analysis by fluorescent in situ hybridization on paraffin-embedded tissue was performed using centromeric probes for chromosomes 1, 2, 6, 10 and 17. We found more than one signal in four of six (66\%) sarcomatoid chromophobe renal cell carcinomas, in both sarcomatoid and adjacent epithelial components. Both primary chromophobe renal cell carcinomas and matched metastases showed single signals for all chromosomes studied in two cases and no abnormalities in the remaining case. We concluded that: (1) both epithelial and sarcomatoid components of sarcomatoid chromophobe renal cell carcinoma show different genetic abnormalities from those characteristic of chromophobe renal cell carcinoma; (2) sarcomatoid chromophobe renal cell carcinomas frequently have multiple gains (polysomy) of chromosomes 1, 2, 6, 10 and 17; (3) distant metastases show the same genetic patterns, usually chromosomal losses (monosomy), found in the primary tumors.

Modern Pathology (2007) 20, 303-309. doi:10.1038/modpathol.3800739; published online 2 February 2007
\end{abstract}

Keywords: sarcomatoid chromophobe renal carcinoma; metastases; FISH; cytogenetic

Most chromophobe renal cell carcinomas are low stage, cured by surgery and have a relatively good prognosis. ${ }^{1}$ Losses of chromosomes 1, 2, 6, 10 and 17 are frequent genetic abnormalities in both classic and eosinophilic chromophobe renal cell carcinomas. ${ }^{2}$ Chromophobe renal cell carcinomas with distant metastases or sarcomatoid transformation are uncommon. ${ }^{3-6}$ Most have been reported as single cases $^{7-23}$ and few cytogenetic data are available. ${ }^{24}$ We sought to identify cytogenetic characteristics of sarcomatoid and metastatic chromophobe renal cell carcinomas by interphase fluorescence in situ hybridization (FISH) analysis.

Correspondence: Dr G Martignoni, MD, Anatomia Patologica, Dipartimento di Patologia, Università di Verona, Strada Le Grazie n. 8, 37134, Verona, Italy.

E-mails: guidomartignoni@univr.it, guidomart@yahoo.com

Received 16 August 2006; revised 5 November 2006; accepted 14 November 2006; published online 2 February 2007

\section{Materials and methods}

Tissue Samples, Histochemical and Immunohistochemical Analyses

We collected six chromophobe renal cell carcinomas with sarcomatoid transformation and three primary chromophobe renal cell carcinomas with matched distant metastases. Two cases with sarcomatoid features were collected from the Department of Pathology, Indiana University Medical Center and four from University Hospital Plzen, Czech Republic. The three metastatic tumors were respectively collected by Hôpital Européen Georges Pompidou, Paris, France, Istituto Europeo di Oncologia, Milan, Italy and Department of Pathology of Innsbruck University, Austria. Seven cases have been reported previously. ${ }^{20,23}$

For all formalin-fixed and paraffin-embedded tumors, serial $5 \mu \mathrm{m}$ sections were stained with 
hematoxylin and eosin, with Hale's colloidal iron technique and immunostained with antibodies recognizing the following markers: parvalbumin (PA-235, Sigma Chemical Company, St Louis, MO, USA; dilution, 1:500), cytokeratin 7 (protease, 1:50; DAKO, Carpinteria, CA, USA) and vimentin (steam, 1:100; Zymed, San Francisco, CA, USA). Immunoreactions were developed using a non-biotin, highly sensitive system (Envision peroxidase detection system, DAKO, Carpinteria, CA, USA) preventing possible false-positive staining due to endogenous biotin present in the tissues.

\section{FISH Analysis}

FISH analysis was performed on five normal tissue samples: two of normal renal parenchyma adjacent to the epithelial component of sarcomatoid chromophobe renal cell carcinomas and three of normal tissue adjacent to metastatizing chromophobe renal cell carcinomas. FISH analysis was performed on all tumors.

From each tumor, $5 \mu \mathrm{m}$ sections were cut from paraffin-embedded blocks. The paraffin was removed from the sections with two 10-min washes in xylene. After hydrating in 100,85 , and $70 \%$ ethanol solutions (10 min), rinsing in distilled water (10 min), and twice in phosphatebuffer solution ( $\mathrm{pH}$ $7,10 \mathrm{~min}$ each), the slides were fixed in methanolacetic acid 3:1 for $10 \mathrm{~min}$ and air-dried. Next, the sections were treated in a $2 \times$ standard saline citrate solution for $15 \mathrm{~min}$ at $37^{\circ} \mathrm{C}$, and then dehydrated in consecutive 70,85 , and $100 \%$ ethanol solutions for $1 \mathrm{~min}$ each and then dried. Next, the sections were bathed in $0.1 \mathrm{mM}$ citric acid $(\mathrm{pH} \mathrm{6)}$ solution at $85^{\circ} \mathrm{C}$ for $1 \mathrm{~h}$. Then they were again dehydrated in a series of ethanol solutions and dried. The tissue was digested by applying $0.75 \mathrm{ml}$ of pepsin (Sigma, St Louis, MO, USA) solution $(4 \mathrm{mg} / \mathrm{ml}$ in $0.9 \%$ $\mathrm{NaCl}, \mathrm{pH} 1.5$ ) to each slide and incubating them in a humidified box for $30 \mathrm{~min}$ at $37^{\circ} \mathrm{C}$. Next, the slides were rinsed with distilled water for few seconds, dehydrated again in graded ethanol solutions and dried. Centromeric probes for chromosomes 1, 2, 6, 10 and 17 (Vysis, Downers Grove, IL, USA) were used. Each probe was diluted 1:100 in tDenHyb1 buffer (Insitus, Albuquerque, NM, USA). Ten microliters of diluted probe were applied to each slide and cover slips were placed over the slides. Denaturation was achieved by incubating the slides at $80^{\circ} \mathrm{C}$ for $10 \mathrm{~min}$ in a humidified box; then hybridization was performed at $37^{\circ} \mathrm{C}$ for $3 \mathrm{~h}$. The cover slips were then removed and the slides were immersed at room temperature in $0.5 \times$ SSC for $2 \mathrm{~min}$, in $50 \%$ formamide $/ 1 \times$ SSC for $5 \mathrm{~min}$, and in $2 \times$ SSC for $2 \mathrm{~min}$. The slides were air dried and counterstained with $10 \mu \mathrm{l}$ DAPI/Antifade (DAPI in Fluorguard, $0.5 \mu \mathrm{g} / \mathrm{ml}$, Insitus, Albuquerque, NM, USA).

The slides were examined using an Axioplan (Zeiss, Germany) with appropriate filters for Spec-
trumOrange (centromeric probes 1 and 2, Abbott), SpectrumGreen (centromeric probes 6, 10 and 17, Abbott), and the UV Filter for the DAPI nuclear counterstain. The signals were recorded with a CCD camera (Axiocam HRm).

Fluorescent in situ signals were evaluated according with previous reports. ${ }^{2,25-27}$ From 100 to 200 neoplastic nuclei were counted and scores followed distinction between sarcomatoid and epithelial components.

\section{Results}

\section{Pathological Findings}

Admixed with the epithelial component of six chromophobe renal cell carcinomas were extensive areas of sarcomatoid spindle cells (Figure 1) with frank nuclear pleomorphism and high mitotic activity (Figure 2).

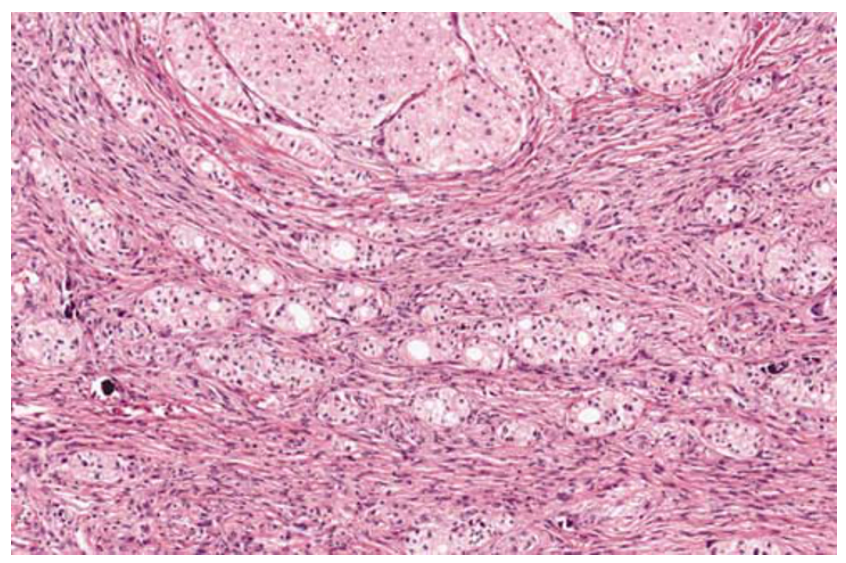

Figure 1 Sarcomatoid chromophobe renal cell carcinoma (hematoxylin and eosin stain, $\times 20$ ).

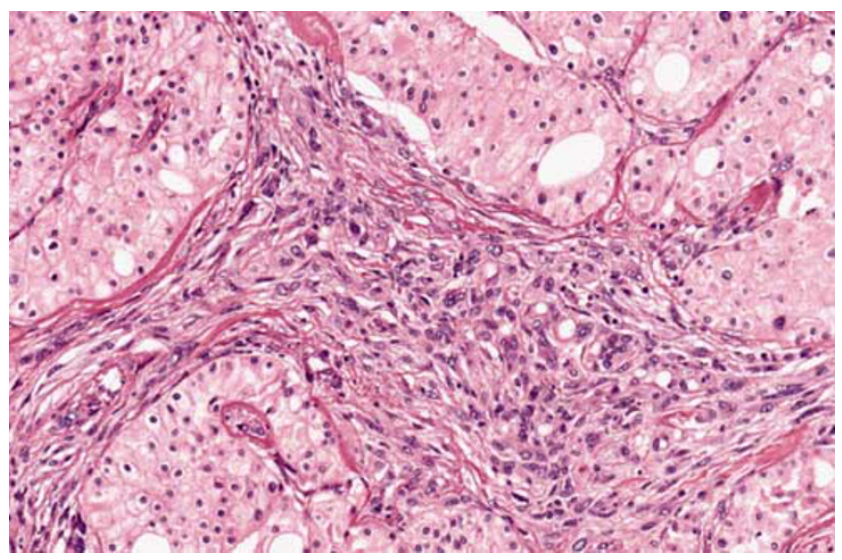

Figure 2 Sarcomatoid chromopobe renal cell carcinoma: epithelial areas intermixed with sarcomatous ones (hematoxylin and eosin stain, $\times 40$ ). 
The pulmonary, pancreatic and retro-peritoneal lymph-nodal metastases of three chromophobe renal cell carcinomas, respectively, occurred 10, 12 and 5 years after surgery.

Hales' colloidal iron stain showed diffuse cytoplasmic positivity in both primary and metastatic lesions of all three metastatic chromophobe renal cell carcinomas and in the epithelial component of all sarcomatoid chromophobe renal cell carcinomas whereas their sarcomatous components displayed patchy staining. Parvalbumin was diffusely positive in all epithelial component of the sarcomatoid chromophobe renal cell carcinomas and both primary and metastatic chromophobe renal cell carcinomas. CK7 was focally positive in the epithelial component of three sarcomatoid chromophobe renal cell carcinomas (5-15\% of neoplastic cells) and in one primary and metastatic chromophobe renal cell carcinoma. Vimentin was positive in the sarcomatoid component of five out of six but it was negative in the epithelial chromophobic cells. Sarcomatous components did not label both parvalbumin and CK7 antibodies.

\section{FISH Analysis}

\section{Normal tissue samples}

Two fluorescent signals were found from 64 to $82 \%$ of nuclei. Three fluorescent signals were found in no more than $16 \%$ of nuclei (Table 1). These findings overlap those described previously in normal renal parenchyma adjacent to chromophobe renal cell carcinomas without sarcomatoid component ${ }^{2,25-27}$ and for this reason we used equal cutoffs to summarize numerical genetic abnormalities observed in the tumors.

\section{Sarcomatoid chromophobe renal cell carcinomas}

The results are present in Table 2 and summarized in Table 3.

DAPI fluorescent stain allowed the distinction between the epithelial neoplastic islands and the sarcomatous areas (Figure 3). We found more than one signal for most chromosomes in four of six $(66 \%)$ sarcomatoid chromophobe renal cell carcinomas (cases no. 1, 2, 4, 5) (Figure 4) in both sarcomatoid and adjacent epithelial components. In the epithelial components of two sarcomatoid chromophobe renal cell carcinomas single signals were, respectively, found for chromosomes 1, 2, 6 and 1, 6, 10 (cases no. 3 and 6).

\section{Metastatic chromophobe renal cell carcinomas}

The results are present in Table 2 and summarized in Table 3.

Both primary chromophobe renal cell carcinomas and matched pulmonary and pancreatic metastases showed single signals for all chromosomes studied. Differently, two signals were found in both primary and matched lymph-nodal metastases for all chromosomes studied.

\section{Discussion}

In this study, we demonstrate that (1) sarcomatoid chromophobe renal cell carcinomas have different genetic abnormalities from those characteristic of this histotype, sharing more than one signal of chromosomes 1, 2, 6, 10 and 17 in both epithelial and sarcomatoid components, (2) distant metastases of chromophobe renal cell carcinoma display the same genetic pattern as the primary tumors and (3) interphase cytogenetic findings by FISH analysis of aggressive chromophobe renal cell carcinoma suggest that chromosomal gains are important for the sarcomatoid transformation of chromophobe renal cell carcinoma but not for its metastatic potential.

The genetic hallmark of chromophobe renal cell carcinomas is the loss of multiple chromosomes from among the chromosomes 1, 2, 6, 10 and 17 (2). Our FISH analysis demonstrates that numerical chromosomal changes in sarcomatoid chromophobe renal cell carcinoma are different from those found in chromophobe renal cell carcinoma composed only of carcinoma. We found more than one signal for most of the tested chromosomes in four of

Table 1 Percentages of different signal number in nuclei from normal tissue

\begin{tabular}{|c|c|c|c|c|c|}
\hline \multirow{2}{*}{$\begin{array}{l}\text { No. } \\
\text { case }\end{array}$} & Chromosome 1 & Chromosome 2 & Chromosome 6 & Chromosome 10 & Chromosome 17 \\
\hline & Percentage of nuclei & Percentage of nuclei & Percentage of nuclei & Percentage of nuclei & Percentage of nuclei \\
\hline
\end{tabular}

Normal renal parenchima adjacent to chromophobe RCC with sarcomatoid transformation

\begin{tabular}{|c|c|c|c|c|c|c|c|c|c|c|c|c|c|c|c|}
\hline 1 & 18 & 72 & 10 & 20 & 76 & 4 & 23 & 71 & 6 & 21 & 76 & 3 & 20 & 74 & 6 \\
\hline 2 & 19 & 76 & 5 & 22 & 74 & 4 & 12 & 82 & 6 & 13 & 78 & 9 & 15 & 73 & 12 \\
\hline \multicolumn{16}{|c|}{ Normal parenchima adjacent to chromophobe $R C C$ with distant metastases } \\
\hline 1 & 22 & 72 & 6 & 24 & 64 & 12 & 13 & 70 & 16 & 15 & 75 & 10 & 21 & 69 & 20 \\
\hline 2 & 12 & 80 & 8 & 11 & 78 & 11 & 11 & 80 & 9 & 25 & 71 & 4 & 19 & 68 & 13 \\
\hline 3 & 23 & 75 & 2 & 20 & 66 & 14 & 28 & 65 & 7 & 17 & 72 & 11 & 10 & 80 & 10 \\
\hline
\end{tabular}


Table 2 Percentages of nuclei with different numbers of signals from neoplastic cells

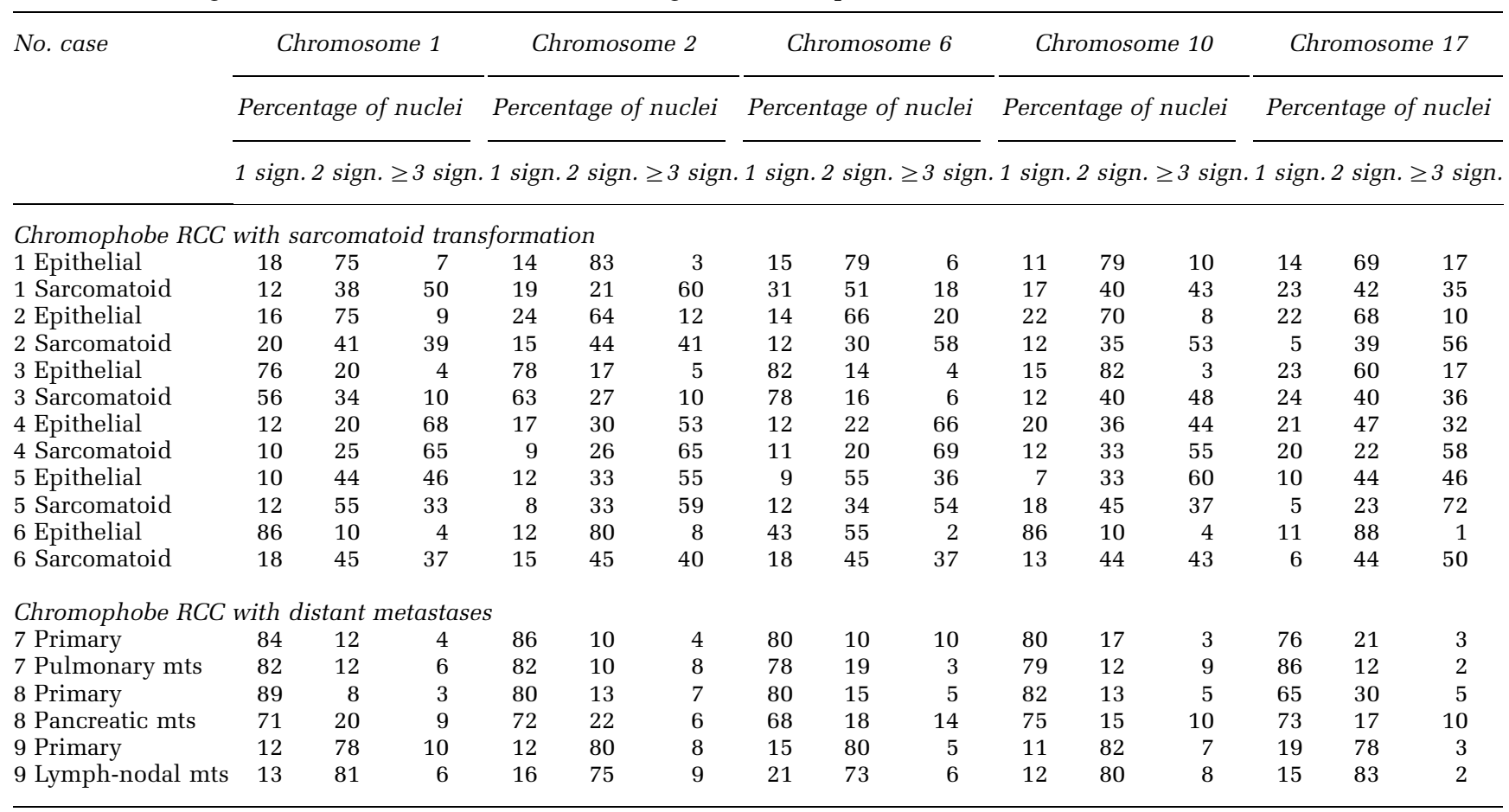

Table 3 Pattern chromosomal summary in aggressive chromophobe renal cell carcinomas

No. case

Chromosome number

\begin{tabular}{lllll}
\hline Chromosome 1 & Chromosome 2 & Chromosome 6 & Chromosome 10 & Chromosome 17
\end{tabular}

Chromophobe RCC with sarcomatoid transformation

$\begin{array}{lll}1 \text { Epithelial } & \text { Dysomy } & \text { Dysomy } \\ \text { 1 Sarcomatoid } & \text { Polysomy } & \text { Polysomy } \\ \text { 2 Epithelial } & \text { Dysomy } & \text { Dysomy } \\ \text { 2 Sarcomatoid } & \text { Polysomy } & \text { Polysomy } \\ \text { 3 Epithelial } & \text { Monosomy } & \text { Monosomy } \\ \text { 3 Sarcomatoid } & \text { Monosomy } & \text { Monosomy } \\ 4 \text { Epithelial } & \text { Polysomy } & \text { Polysomy } \\ \text { 4 Sarcomatoid } & \text { Polysomy } & \text { Polysomy } \\ 5 \text { Epithelial } & \text { Polysomy } & \text { Polysomy } \\ \text { 5 Sarcomatoid } & \text { Polysomy } & \text { Polysomy } \\ \text { 6 Epithelial } & \text { Monosomy } & \text { Dysomy } \\ \text { 6 Sarcomatoid } & \text { Polysomy } & \text { Polysomy }\end{array}$

Dysomy

Monosomy

Dysomy

Polysomy

Monosomy

Monosomy

Polysomy

Polysomy

Polysomy

Polysomy

Monosomy

Polysomy

Dysomy
Polysomy
Dysomy
Polysomy
Dysomy
Polysomy
Polysomy
Polysomy
Polysomy
Polysomy
Monosomy
Polysomy

Monosomy

Monosomy

Monosomy

Monosomy

Dysomy

Dysomy

\begin{tabular}{llll} 
Monosomy & Monosomy & Monosomy & Monosomy \\
Monosomy & Monosomy & Monosomy & Monosomy \\
Monosomy & Monosomy & Monosomy & Monosomy \\
Monosomy & Monosomy & Monosomy & Monosomy \\
Dysomy & Dysomy & Dysomy & Dysomy \\
Dysomy & Dysomy & Dysomy & Dysomy \\
\hline
\end{tabular}

Dysomy

Polysomy

Dysomy

Polysomy

Dysomy

Polysomy

Polysomy

Polysomy

Polysomy

Polysomy

Dysomy

Polysomy

$\begin{array}{ll}7 \text { Primary } & \text { Monosomy } \\ 7 \text { Pulmonary mts } & \text { Monosomy } \\ 8 \text { Primary } & \text { Monosomy } \\ 8 \text { Pancreatic mts } & \text { Monosomy } \\ 9 \text { Primary } & \text { Dysomy } \\ 9 \text { Lymph-nodal mts } & \text { Dysomy }\end{array}$

\begin{tabular}{llll} 
Monosomy & Monosomy & Monosomy & Monosomy \\
Monosomy & Monosomy & Monosomy & Monosomy \\
Monosomy & Monosomy & Monosomy & Monosomy \\
Monosomy & Monosomy & Monosomy & Monosomy \\
Dysomy & Dysomy & Dysomy & Dysomy \\
Dysomy & Dysomy & Dysomy & Dysomy \\
\hline
\end{tabular}

\begin{tabular}{llll} 
Monosomy & Monosomy & Monosomy & Monosomy \\
Monosomy & Monosomy & Monosomy & Monosomy \\
Monosomy & Monosomy & Monosomy & Monosomy \\
Monosomy & Monosomy & Monosomy & Monosomy \\
Dysomy & Dysomy & Dysomy & Dysomy \\
Dysomy & Dysomy & Dysomy & Dysomy \\
\hline
\end{tabular}

six (66\%) sarcomatoid chromophobe renal cell carcinomas in both the sarcomatoid and adjacent epithelial component. Differently, two out of three metastatic chromophobe renal cell carcinoma showed one signal for all chromosomes in both primary and metastatic chromophobe renal cell carcinomas. We conclude that these multiple chro- mosomal gains could play a role for sarcomatoid transformation of chromophobe renal cell carcinoma and do not characterize metastatic chromophobe renal cell carcinoma, neither in the renal primary nor in the metastases.

In the largest series reported to date, Akhtar et al ${ }^{24}$ presented six cases of sarcomatoid chromophobe 


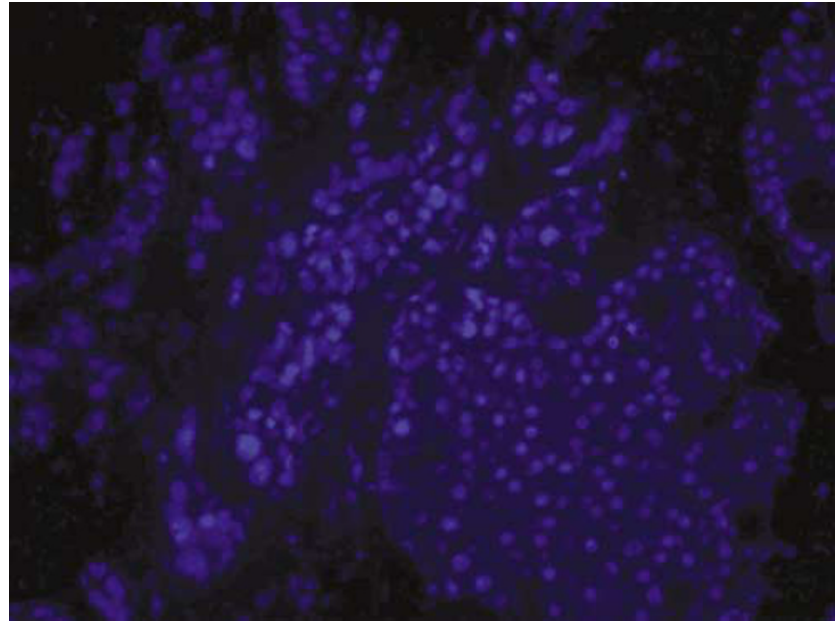

Figure 3 Sarcomatoid chromophobe renal cell carcinoma: DAPI fluorescent counterstain on formalin-fixed paraffin embedded tissue allows distinction between epithelial and sarcomatous components $(\times 40)$.

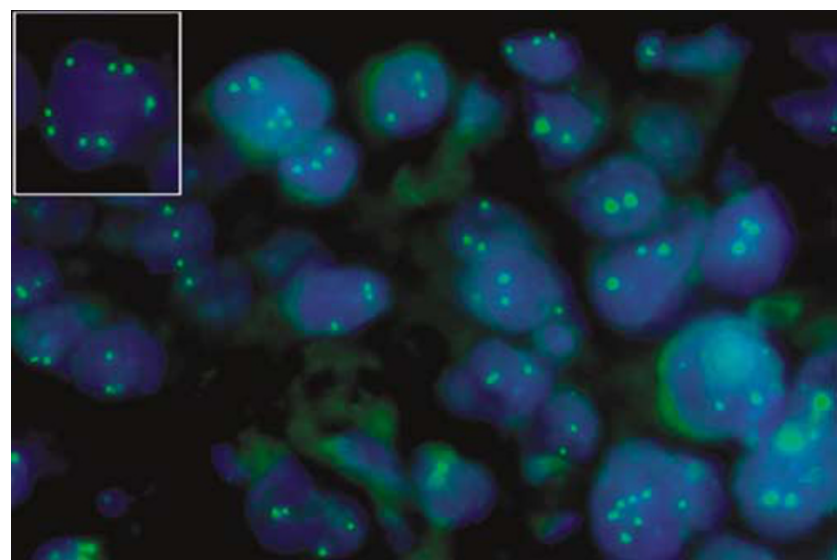

Figure 4 Sarcomatoid chromophobe renal cell carcinoma: FISH analysis showing numerical chromosome 17 gains (SpectrumGreen, $\times 63)$.

renal cell carcinoma. DNA ploidy analysis revealed that progression to high-grade sarcomatoid areas was associated with the development of pronounced aneuploidy, while the areas of the typical chromophobe renal cell carcinoma were near-diploid or even hypodiploid. Our data are in agreement with those findings. Again, our case no. 3 is even similar to the two cases described by Akhtar et $a l^{10}$ and Cserni et $a l^{14}$ in distinctive reports sharing a predominantly hypodiploid pattern in both sarcomatoid and epithelial component.

Sarcomatoid renal cell carcinomas are generally considered to be the result of a process of dedifferentiation of an epithelial type of renal cell carcinoma and one would expect that the dedifferentiated malignant cells would conserve the original genomic changes that characterize the malignant epithelial tumor cells from which they are thought to be derived. ${ }^{28}$ However, different cytogenetic data have been reported. Most analyses have shown complex chromosomal rearrangements, suggesting the alteration of multiple genes in sarcomatoid transformation of clear cell and papillary renal cell carcinomas. Dal Cin et $a l^{29}$ combined their results with a few other cases from the literature, and concluded that genomic changes in most sarcomatoid renal cell carcinomas appeared to have little in common with those characterizing the underlying carcinoma. However in three studies, 10 of 13 sarcomatoid tumors demonstrated the specific genetic change associated with the clear cell subtype, that is loss of (part of) $3 p .{ }^{29-31}$ Cheng et al studied sarcomatoid clear cell renal cell carcinoma and found that Xchromosome inactivation analysis provide strong evidence for a common progenitor cell origin for both the clear cell and sarcomatoid components. However, in the same study the authors found by loss of heterozygosity analysis a genetic heterogeneity within both components and they concluded that although molecular heterogeneity was clearly present, the data did not provide sufficient evidence to establish a multistep model for neoplastic transformation and progression in renal cell carcinomas. ${ }^{32}$ Two sarcomatoid papillary renal cell carcinomas were described to have complex karyotypes with no abnormalities in common between epithelial and sarcomatoid areas of the same tumor ${ }^{33}$ but a case report showed trisomy of chromosome 7 and 17 in sarcomatoid papillary renal cell carcinoma in both components. ${ }^{34}$ In 12 sarcomatoid renal cell carcinomas without any distinction among the renal cell histotypes of the carcinomatous component, Jiang et $a l^{35}$ found either losses than gains with an average of 8.6 aberrations per tumor and concluded that sarcomatoid renal cell carcinomas are genetically complex.

In this study, we examined selected chromosomes that usually characterize chromophobe renal cell carcinomas without sarcomatoid component, thus we do not exclude the fact that other molecular abnormalities, in association with those found, can play a role or be the prime factor in the sarcomatoid transformation of chromophobe renal cell carcinomas.

Application of molecular techniques to the study of renal epithelial neoplasms have been widely used. ${ }^{36}$ The interphase FISH analysis used in our study has the advantage of allowing evaluation of fluorescent signals with distinction between sarcomatoid and epithelial components of the same tumor.

Our results demonstrate that metastatic chromophobe renal cell carcinomas show the same genetic pattern in both primary and metastatic tumors. A very few data reporting the genetic analysis in both primary and metastatic chromophobe renal cell carcinoma are present in the literature. Renshaw et al reported a DNA ploidy analysis of a primary chromophobe renal cell carcinoma which metastatized to the liver, revealing a diploid pattern. ${ }^{37}$ This 
pattern is similar to one of our case (no. 9) which metastatized to the lymph-nodes. Dijkhuizen et al ${ }^{38}$ reported chromosomal changes in a splenic metastasis of a chromophobe renal cell carcinoma showing in addition to the extensive chromosome losses specific for the chromophobe subtype, structural rearrangements involving chromosomes 1, 5, 12, 15 and 18. They concluded that determining whether or not the observed structural changes were important for the metastatic behavior of chromophobe renal cell carcinomas still remained unclear. Among other histotypes various gains and losses of DNA sequence copy number have been found when comparing primary clear cell or papillary renal cell carcinomas and metastatic lesions. ${ }^{39-44}$

The histochemical and immunohistochemical analyses showed results as expected, regarding the epithelial component. ${ }^{23,45,46}$ Parvalbumin and CK7 showed immunoexpression in the chromophobic cells whereas vimentin was absent; Hale's colloidal iron stain was diffusely positive. Moreover sarcomatoid component of chromophobe renal cell carcinomas displayed a patchy staining with Hale's colloidal iron and did not for parvalbumin and CK7.

In conclusion, our interphase cytogenetic findings by FISH analysis of aggressive chromophobe renal cell carcinomas suggest that multiple chromosomal gains are important for the sarcomatoid transformation of chromophobe renal cell carcinoma but not for its metastatic potential.

\section{Acknowledgements}

We thank Dr Giacomo Puppa (Istituto Europeo di Oncologia, Milan, Italy), Cecile Badoual (Hopital Europeen Georges Pompidou, Paris, France) and Gregor Mikuz (University of Innsbruck, Austria) for providing metastatic chromophobe renal cell carcinomas paraffin-embedded blocks.

Grant have been supported by Fondazione Cassa di Risparmio di Verona.

\section{References}

1 Eble JN, Sauter G, Epstein JI, et al (eds). Tumours of the urinary system and male genital organs. World Health Organization Classification of Tumours: Lyon, IARC, 2004.

2 Brunelli M, Eble JN, Zhang S, et al. Eosinophilic and classic chromophobe renal cell carcinomas have similar frequent losses of multiple chromosomes from among chromosomes 1, 2, 6, 10, 10 and 17, and this pattern of genetic abnormalities is not present in renal oncocytoma. Mod Pathol 2005;18:161-169.

3 Martignoni G, Eble JN, Brunelli M, et al. Chromophobe renal cell carcinoma: a clinicopathologic study of 100 cases. Mod Pathol 2003;1:161A.

4 de Peralta-Venturina M, Moch H, Amin M, et al. Sarcomatoid differentiation in renal cell carcinoma: a study of 101 cases. Am J Surg Pathol 2001;25:275-284.
5 Cheville JC, Lohse CM, Zincke H, et al. Sarcomatoid renal cell carcinoma: an examination of underlying histologic subtype and an analysis of associations with patient outcome. Am J Surg Pathol 2004;28: 435-441.

6 Onishi T, Oishi Y, Yanada S, et al. Prognostic implications of histological features in patients with chromophobe cell renal carcinoma. BJU Int 2002;90: 529-532.

7 Nagashima Y, Okudela K, Osawa A, et al. Chromophobe renal cell carcinoma with sarcomatoid change. A case report. Pathol Res Pract 2000;196:647-651.

8 Mai KT, Veinot JP, Collins JP. Sarcomatous transformation of chromophobe cell renal carcinoma. Histopathology 1999;34:557-559.

9 Kuroda N, Hayashi Y, Itoh H. A case of chromophobe renal cell carcinoma with sarcomatoid foci and a small daughter lesion. Pathol Int 1998;48:812-817.

10 Akhtar M, Kfoury H, Kardar A, et al. Sarcomatoid chromophobe cell carcinoma of the kidney. J Urol Pathol 1996;4:155-166.

11 Hirokawa M, Shimizu M, Sakurai T, et al. Sarcomatoid renal cell carcinoma with chromophobe cell foci. Report of a case. APMIS 1998;106:993-996.

12 Tardio JC. Chromophobe cell renal carcinomas with sarcomatoid areas. Histopathology 2000;36:184-185.

13 Gomez-Roman JJ, Mayorga-Fernandez M, FernandezFernandez F, et al. Sarcomatoid chromophobe cell renal carcinoma: immunohistochemical and lectin study in one case. Gen Diagn Pathol 1997;143:63-69.

14 Cserni G, Kovacs BR, Tarjan M, et al. Sarcomatoid renal cell carcinoma with foci of chromophobe carcinoma. Pathol Oncol Res 2002;8:142-144.

15 Shimomura T, Ikemoto I, Yamada H, et al. Sarcomatoid renal cell carcinoma with a chromophobe component producing beta-human chorionic gonadotropin. Int J Urol 2005;12:835-837.

16 Itoh T, Chikai K, Ota S, et al. Chromophobe renal cell carcinoma with osteosarcoma-like differentiation. Am J Surg Pathol 2002;26:1358-1362.

17 Joubert M, Cassagnau E, Boullanger P, et al. Sarcomatoid variant of chromophobe renal cell carcinoma. Report of 2 cases. Ann Pathol 1997;17:392-395.

18 Redondo Martinez E, Rey Lopez A, Rivero Vera JC, et al. Renal carcinoma of sarcomatoid chromophobe cells. Arch Esp Urol 2000;53:700-707.

19 Abrahams NA, Ayala AG, Czerniak B. Chromophobe renal cell carcinoma with sarcomatoid transformation. Ann Diagn Pathol 2003;7:296-299.

20 Hes O, Michal M, Kinkor Z, et al. Sarcomatous chromophobe cell renal carcinoma. 2 case reports. Cesk Patol 1999;35:15-19.

21 Parada D, Pena K, Moreira O. Sarcomatoid chromophobe renal cell carcinoma. A case report and review of the literature. Arch Esp Urol 2006;59:209-214.

22 Badoual C, Tissier F, Lagorce-Pages C, et al. Pulmonary metastases from a chromophobe renal cell carcinoma: 10 years' evolution. Histopathology 2002;40:300-302.

23 Martignoni G, Pea M, Brunelli M, et al. CD10 is expressed in a subset of chromophobe renal cell carcinomas. Mod Pathol 2004;17:1455-1463.

24 Akhtar M, Tulbah A, Kardar AH, et al. Sarcomatoid renal cell carcinoma: the chromophobe connection. Am J Surg Pathol 1997;21:1188-1195.

25 Brunelli M, Eble JN, Zhang S, et al. Metanephric adenoma lacks the gains of chromosomes 7 and 17 and loss of $\mathrm{Y}$ that are typical of papillary renal cell 
carcinoma and papillary adenoma. Mod Pathol 2003; 16:1060-1063.

26 Cossu-Rocca P, Eble JN, Delahunt B, et al. Renal mucinous tubular and spindle carcinoma lacks the gains of chromosomes and 17 and losses of chromosome $\mathrm{Y}$ that are prevalent in papillary renal cell carcinoma. Mod Pathol 2006;19:488-493.

27 Brunelli M, Eble JN, Zhang S, et al. Gains of chromosomes 7, 17, 12, 16, and 20 and loss of Y occur early in the evolution of papillary renal cell neoplasia: a fluorescent in situ hybridisation study. Mod Pathol 2003;16:1053-1059.

28 Delahunt B. Sarcomatoid renal carcinoma: the final common dedifferentiation pathway of renal epithelial malignancies. Pathology 1999;31:185-190.

29 Dal Cin P, Sciot R, Van Poppel H, et al. Chromosome changes in sarcomatoid renal carcinomas are different from those in renal cell carcinomas. Cancer Genet Cytogenet 2002;134:38-40.

30 Presti Jr JC, Rao PH, Chen Q, et al. Histopathological, cytogenetic, and molecular characterization of renal cortical tumors. Cancer Res 1991;51:1544-1552.

31 Anglard P, Trahan E, Liu S, et al. Molecular and cellular characterization of human renal cell carcinoma cell lines. Cancer Res 1992;52:348-356.

32 Jones TD, Eble JN, Wang M, et al. Clonal divergence and genetic heterogeneity in clear cell renal cell carcinomas with sarcomatoid transformation. Cancer 2005;104:1195-1203.

33 el-Naggar AK, Ro JY, Ensign LG. Papillary renal cell carcinoma: clinical implication of DNA content analysis. Hum Pathol 1993;24:316-321.

34 Cohen RJ, McNeal JE, Susman M, et al. Sarcomatoid renal cell carcinoma of papillary origin. A case report and cytogenic evaluation. Arch Pathol Lab Med 2000;124:1830-1832.

35 Jiang F, Moch H, Richter J, et al. Comparative genomic hybridization reveals frequent chromosome $13 q$ and $4 \mathrm{q}$ losses in renal carcinomas with sarcomatoid transformation. J Pathol 1998;185:382-388.
36 Jones TD, Eble JN, Cheng L. Application of molecular diagnostic techniques to renal epithelial neoplasms. Clin Lab Med 2005;25:279-303.

37 Renshaw AA, Henske EP, Loughlin KR, et al. Aggressive variants of chromophobe renal cell carcinoma. Cancer 1996;78:1756-1761.

38 Dijkhuizen T, van den Berg E, Storkel S, et al. Chromosome changes in a metastasis of a chromophobe renal cell tumor. Cancer Genet Cytogenet 1998;105:86-89.

39 Bissig H, Richter J, Desper R, et al. Evaluation of the clonal relationship between primary and metastatic renal cell carcinoma by comparative genomic hybridization. Am J Pathol 1999;155:267-274.

40 Gronwald J, Hadaczek P, Storkel S, et al. Molecular evidence for derivation of metastatic cells from minor subclones of primary clear renal cell carcinomas. Cancer Detect Prev 1999;23:479-484.

41 Gunawan B, von Heydebreck A, Fritsch T, et al. Cytogenetic and morphologic typing of 58 papillary renal cell carcinomas: evidence for a cytogenetic evolution of type 2 from type 1 tumors. Cancer Res 2003;63: 6200-6205.

42 Gronwald J, Storkel S, Holtgreve-Grez $\mathrm{H}$, et al. Comparison of DNA gains and losses in primary renal clear cell carcinomas and metastatic sites: importance of $1 \mathrm{q}$ and $3 p$ copy number changes in metastatic events. Cancer Res 1997;57:481-487.

43 Moch H, Mihatsch MJ. Genetic progression of renal cell carcinoma. Virchows Arch 2002;441:320-327.

44 Jiang F, Richter J, Schraml P, et al. Chromosomal imbalances in papillary renal cell carcinoma: genetic differences between histological subtypes. Am J Pathol 1998;153:1467-1473.

45 Martignoni G, Pea M, Chilosi M, et al. Parvalbumin is constantly expressed in chromophobe renal carcinoma. Mod Pathol 2001;14:760-767.

46 Adley BP, Papavero V, Sugimura J, et al. Diagnostic value of cytokeratin 7 and parvalbumin in differentiating chromophobe renal cell carcinoma from renal oncocytoma. Anal Quant Cytol Histol 2006;28:228-236. 